\title{
Design of Business Intelligence in Learning Systems Using iLearning Media
}

\author{
Sudaryono ", Untung Rahardja, Ahmad Roihan \\ Department of Informatics Engineering, Raharja College, Indonesia
}

Copyright $(2017$ by authors, all rights reserved. Authors agree that this article remains permanently open access under the terms of the Creative Commons Attribution License 4.0 International License

\begin{abstract}
In the era of modern learning, e-Learning system utilized the school as a media institution of learning that can control the effectiveness of student learning. Some of your existing online learning system is not yet able to support teaching and learning activities based on student (student oriented). This research aims to harness and develop a system that is running by adding the concept of Business Intelligence in order to measure interest and activity of students in learning system application wear online. The methods used in this research are with the method of OLAP by utilizing data mart and user needs analysis. Design of business intelligence using user interface components namely the dashboard so that the information displayed in real time and accurate. The next of this research will be known how much interest and the liveliness of the students in the following learning interactively and communicative.
\end{abstract}

Keywords Business Intelligence, OLAP, Data Mart, Dashboard

\section{Introduction}

Current technology is growing very fast. It was followed by the development of technology in the delivery of information that is often referred to as information systems. The development of information systems requires various factors supporting the display of the application as well as participation from the user. In building the application needed a simple and attractive display for visitors so that user participation is expected to support the success of information systems that produce the level of satisfaction of the users of the information system or the application provider agencies.

Instructional system was designed with the main objective to improve the effectiveness of learning. Operationally, the system requires instructional learning theories as the Foundation footing system development and its possible applications. Likewise, instructionalmedia online learning system, as the delivery medium, it should be realized that online learning is not the sole factor that determines the quality of learning. Current research tells us that a learning environment using media technology can increase the value of those students, their attitude towards learning, and evaluation of their learning experience. Technology can also help improve the interactions between teachers and students, and making the process of learning based on student (student oriented). However, there is alsoresearch that mentioned the negative impact of this learning environment, that students experience the feeling of isolation, frustration, anxiety, and confusion or reduce interest in field of study [1].

In this study, the use of information systems-based education will be used mostly by students and teachers to interact in a virtual world. So either the vision or mission of the school can be realised, with the presence of this information system, students who are less able to follow lessons will find it helpful so that in the development of information systems, both students and teachers need to be proactively involved with strategic decisions in making this application. In other words it takes active participation of the users of bothstudents as well as teachers, so that later developed systems can run effectively.

Teaching and learning need to be planned so that learning takes place properly and achieve the expected results. Each planning deals with thoughts about what should be done. Teaching and learningprogram planning estimates on the actions which will be performed at the time of carrying out the instruction. Contents planning, i.e. set up and assign learning elements, such as the purpose, materials or contents, methods, tools and resources as well as the assessment of [1].

Salem Alkhalaf et.al. [2] in his research in the journal of Social and Behavioral Sciences Procedia explained that e-Learning systems are a technological development that have reformed and restructured the delivery and interaction of students and teachers with coursematerials and related resources. Guo-Heng Luo et.al. [3] in her research describes the benefits of using e-Learning, i.e. to overcomephysical access limitations, certain institutions have leveraged 
theInternet to facilitate teaching internati-onal trade, building e-learning systems that include teaching videos and slides. Learners can watch the teaching videos anywhere and at any time through the Internet. They can also download and study slides and submit homework through the system. This teaching method is similar to the traditional teaching method, allowing learners to conveniently studyinternational trade by using the Internet.

Participation rates and user satisfaction will influence the success of the implementation of the system. Therefore it took the design of the intelligence systems that can support teachers in terms of decision making. In practice there needs to be a survey or researchso that in its implementation can be known also lack system and satisfaction of students and teachers in the use of information systems. ilearning media is a media which provide learning solutions by leveraging Information Communication and Technology (ICT) so that learning becomes more enjoyable because it has the concept of learning, play, pray and work. It is therefore in support of effectiveclass accompanied by communication between teachers and students learning system design required iLearning Media intelligence, so the goal of the learning can be accomplished very well.

\section{Problems}

Enthusiastic students against the application of online learning are still constrained. It is also troubled by a number of factors, among them many students who don't want to know the development ofthe internet, internet usage fee is so expensive for the size of the pockets of students, and other factors underlying disease. The next problem that is giving a sense of the teachers in order to implement this application, so as to achieve the purpose of education is carried out. Then also on socialization of students in order to use this application with high enthusiasm, so students get science perfectly. Any other matters provided to teachers and students to interact about the subject matter outside of school hours.

There are several principal problems in the design and implementation of a learning system, i.e. on how to make the learning systemin order to be attractive to users, be it from the design of the system or user interface is ease of use. Then how is that teachers and students can use this application with enthusiasm is high, so that the goal of education is carried out.

Another issue that is how manfaatkah systems to Knowledge Media iLearning students about the subject matter, how to design a system that support teachers in making a decision.

Of the problems that have been identified, there are three issues that are limited to minimize the time and cost in this research. The problem is how to create a system to support teaching and learning activities based on student (student oriented) and the application of Business Intelligence in the system of learning online with the object of research in SMK AL Fattah within one semester. The nextsystem is applied or used for interaction between teachers and students in the process of teaching and learning activities and to find out how the interest and activity of users in wearing the learning system applications.

Based on the problems that had already been restricted before, then there are three problem formulation in detail that appear in this research, first is the design of the intelligence system to support teaching and learning activities based on student (studentoriented). Both i.e. the application of the system used for interactive learning activities and communicative. A third i.e. measuring the interest and activity of users in the learning system with application to wear the concept of Business Intelligence in SMK AL Fattah.

\section{Literature Review}

Based on the concept that was built in this research is an addition of a concept or remodelling of the system who've built before, then the research is highly relevant to the design of the system itself.Research-research that has been done before is relevant, including:

1. Guo-Heng Luo, Eric Zhi-Feng Liu, Hung-Wei Kuo, Shyan-Ming Yuan (2014) in their research entitled "Design and Implementation of a Simulation-Based Learning System for International Trade". In the traditional instructional method used in international trade, teachers provide knowledge to learners by lecturing using slides and setting assignments; however, these methods merely deliver international trade knowledge rather than facilitating student development of relevant skills. To solve these problems, we proposed a simulationbased learning system for international trade, combining international trade-process simulation and business letter writing. We investigated learner opinions toward the system and the quality of business letters by using quantitative and qualitative analyses. Regarding the results, learners perceived that the proposed system improved their knowledge of international trade and business English.[2]

2. Salem Alkhalaf, Steve Drew, Rayed Alghamdi, Osama Alfarraj (2012) in their research entitled "E-learning system on higher education institutions in KSA: attitudes and perceptions of faculty members". This paper presents findings from a study evaluating eLearning systems in the Kingdom of Saudi Arabia (KSA). E-Learning Systems are a technological development that have reformed and restructured the delivery and interaction of students and teachers with course materials and related resources. E-Learning systems have been widely used in developed countries and have recently become more popular in many developing countries. To date, however, little attention 
has been paid to the issue of measuring the impact of eLearning on academic staff at higher educational institutions in the Kingdom of Saudi Arabia. Responding to this gap in the literature, this study investigates the impact of e-Learning systems in higher education institutions in this context. A survey based on the IS Success/Impact Measurement Framework was executed in a sample population of faculty members using e-Learning in two top universities in the KSA. The findings of this study show positive academics' attitudes towards eLearning systems in higher education, helping faculty members to improve their job performance, and educational organizations to provide better and new products and services to users.[3]

3. Untung Rahardja, Sudaryono, Irwan Nurdin (2014) in their research entitled "Implementasi iMe (iLearning Media) Dalam Mendukung Sistem Pembelajaran iLearning Pada Perguruan Tinggi". iLearning is a method of lecturing in colleges Raharja who use the $\mathrm{iPad}$ as a media to facilitate the learning process of students. Given this method, students can learn, work, pray and play with iPad. The term is known as 4B. iLearning Media or shortened by the name iMe is a web application that is created and can be used by all students of colleges Raharja to explore their creativity in learning. This is an online learning system that facilitates student learning, because it can be done anywhere and anytime. It was concluded that the contribution of the iMe can be used as a medium of information for learning systems for the entire community Raharja colleges.[4]

4. L. Jegatha Deborah, R. Baskaran, A. Kannan (2012) in their research entitled "Learning styles assessment and theoretical origin in an E-learning scenario: a survey". The performance of the learners in E-learning environments is greatly influenced by the nature of the posted E-learning contents. In such a scenario, the performance of the learners can be enhanced by posting the suitable E-learning contents to the learners based on their learning styles. Hence, it is very essential to have a clear knowledge about various learning styles in order to predict the learning styles of different learners in E-learning environments. However, predicting the learning styles needs complete knowledge about the learners past and present characteristics. Since the knowledge available about learners is uncertain, it can be resolved through the use of Fuzzy rules which can handle uncertainty effectively. The core objective of this survey paper is to outline the working of the existing learning style models and the metrics used to evaluate them. Based on the available models, this paper identifies Felder-Silverman learning style model as the suitable model for E-learning and suggests the use of Fuzzy rules to handle uncertainty in learning style prediction so that it can enhance the performance of the E-learning system.[5]
5. Matjaz Debevca, Zoran Stjepanovic and Andreas Holzingerc (2014) in their research entitled "Development and evaluation of an e-learning course for deaf and hard of hearing based on the advanced Adapted Pedagogical Index method". Web-based and adapted e-learning materials provide alternative methods of learning to those used in a traditional classroom. Within the study described in this article, deaf and hard of hearing people used an adaptive e-learning environment to improve their computer literacy. This environment included streaming video with sign language interpreter video and subtitles. The courses were based on the learning management system Moodle, which also includes sign language streaming videos and subtitles. A different approach is required when adapting e-learning courses for the deaf and hard of hearing: new guidelines must be developed concerning the loading and display of video material. This is shown in the example of the e-learning course, ECDL (European Computer Driving Licence). The usability of the e-learning course is analyzed and confirmed using two methods: first, the Software Usability Measurement Inventory (SUMI) evaluation method, and second, the Adapted Pedagogical Index (AdaPI), which was developed as part of this study, and gives an index to measure the pedagogical effectiveness of e-learning courses adapted for people with disabilities. With 116 participants, of whom 22 are deaf or hard of hearing, the e-learning course for the target group has been found suitable and appropriate according to both evaluation methods.[7]

6. Hsin-Kai Chou, I-Chun Lin, Lin-Chung Woung, Ming-Tsu Tsai (2012) in their research entitled "Engagement in E-Learning Opportunities: An Empiricial Study on Patient Education using Expectation Confirmation Theory". Medical e-learning technology is widely employed to create an online platform for patients and healthcare providers alike. However, there are few studies that have investigated the reasons why some users reject e-learning technology usage after their initial experience. This study was conducted with the aim to better understand the factors leading to patients' continued usage of e-learning technologies. The theoretical foundation was based on the Expectation Confirmation Theory (ECT). The questionnaire survey was conducted during a two-month period and covered a total sample of 281 outpatients in a regional-teaching hospital. We found that the intention to continue e-learning usage was significantly related to patients' education level, expectation, perceived performance, confirmation and satisfaction. The use of this ECT model may provide administrators in the healthcare industry insights into the implementation of e-learning technologies. This research also opens up a new direction and enhances the completeness of related researches in the fields of medical informatics and health education.[9] 
7. Eva Marti'nez-Caro (2009) in their research entitled "Factors Affecting Effectiveness in E-Learning: An Analysis in Production Management Courses". E-learning may help to open up new channels for the traditional teaching of engineering but there are many questions about what makes e-learning an effective and satisfactory method, in particular, in the field of industrial engineering. This article evaluates the potential factors affecting the effectiveness of engineering e-learning courses by applying structural equation modeling in a sample of students of multiple production management courses for industrial engineering students. This way, the gaps and methodological weaknesses detected in prior studies has been avoided. The findings of this study suggest that interaction is key to getting successful outcomes, that the right mixture of human and technology must be found, that it is crucial to teach students to learn online and that special attention must be directed to non-traditional students who have the additional pressure of resolving time conflicts between e-learning, work and/or family life. These findings can help engineering colleges and schools offering e-learning courses to learn more about how to enhance students' success.[10]

8. Soraya Benchicou, Mohamed Aichouni and Driss Nehari (2010) in their research entitled "E-learning in engineering education: a theoretical and empirical study of the Algerian higher education institution". Technology-mediated education or e-learning is growing globally both in scale and delivery capacity due to the large diffusion of the ubiquitous Information and Communication Technologies (ICT) in general and the web technologies in particular. This statement has not yet been fully supported by research, especially in developing countries such as Algeria. The purpose of this paper was to identify directions for addressing the needs of academics in higher education institutions in Algeria in order to adopt the e-learning approach as a strategy to improve quality of education. The paper will report results of an empirical study that measures the readiness of the Algerian higher education institutions towards the implementation of ICT in the educational process and the attitudes of faculty members towards the application of the e-learning approach in engineering education. Three main objectives were targeted, namely: (a) to provide an initial evaluation of faculty members' attitudes and perceptions towards web-based education; (b) reporting on their perceived requirements for implementing e-learning in university courses; (c) providing an initial input for a collaborative process of developing an institutional strategy for e-learning. Statistical analysis of the survey results indicates that the Algerian higher education institution, which adopted the Licence - Master and Doctorate educational system, is facing a big challenge to take advantage of emerging technological innovations and the advent of e-learning to further develop its teaching programmes and to enhance the quality of education in engineering fields. The successful implementation of this modern approach is shown to depend largely on a set of critical success factors that would include: 1 . The extent to which the institution will adopt a formal and official e-learning strategy; 2. The extent to which faculty members will adhere and adopt this strategy and develop ownership of the various measures in the context of their teaching and research responsibilities; 3 . The extent to which the university will offer adequate support in terms of training, software platform administration, online resource development and impact monitoring and assessment.[11]

Of the eight existing review Literature, has been a lot of research regarding the Design and implementation of e-learning system, Factors Affecting Effectiveness in E-Learning, and Evaluation Models of Success and Acceptance of E-Learning. Suryo quarter Guritno et.al. [13] explaining that the main focus of a review of the literatureor literature review in a study is to find out whether other researchers have found answers to the research questions that we deduce.If can find the answers to such research in various libraries or report the most actual research results, then we don't need to do the same research. Therefore, it can be concluded that there has been no research that specifically deals with the design of Business Intelligence in systems learning iLearning Media used to support a teacher in making a decision.

\section{Troubleshooting}

Untung Rahardja et.al. (2011) describes that the system iLearning (integrated Learning) or in English called the integrated learning system that is applied is one form to improve the quality of education towards a modern and quality [14].

iLearning media is a media which provide learning solutions by leveraging information and communication technologies so that learning becomes more enjoyable because it has the concept of learning,play, pray and work. Systems used in this study, is part of a system based on Media iLearning a CMS (Content Management System) of WordPress. WordPress is an open source application (open source) is used as a very popular blog engine (blog engine). WordPress is built using the PHP programming language and have the database from the MySQL DBMS. PHP and MySQL is open source software (open source software). This is evident in Figure 1 here,

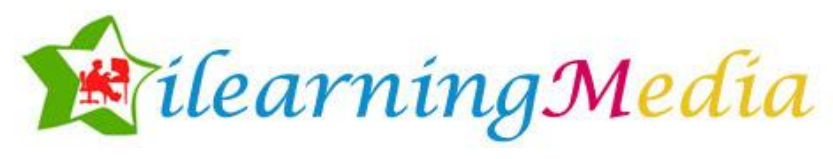

Source: http://ilearning.me/

Figure 1. iLearning Media logo 
This research uses a system of iLearning Media so some featuresalready available in it, including in terms of design and design of existing systems. Therefore, this study just emphasizes the process of designing Business Intelligence learning system iLearning Media in SMK AL Fattah.

After a review of system design based on level and Media iLearning needs then required in supporting the goal of this research is to add the plugin in the iLearning Media so that the system has additional functionality that is Business Intelligence. Therefore, in this study required additional plugin PHP Code For Posts and User Role Editor.

The dashboard is one tool or device in Business Intelligence in the form of visual display of important information that is used on theuser interface to support a decision. BI architecture according to Efraim Turban (2011) "A BI system has four major components: a data warehouse, with its source data ; business analytics, a collection of tools for manipulating, mining, and analyzing the data in thedata warehouse; business performance management (BPM) for monitoring and analyzing performance; and a user interface (e.g., adashboard) "[15].

In the feasibility study needs analysis system on smkalfattah.ilearning.me, the user need not view can only be accessed by the user's iMe user and admin, but widely accessible without having to go into the system of iLearning Media. Then it takes a look at the dashboard page that can be accessed by everyone (public). the dashboard itself is one of the tools or devices that belong to the four components of Business Intelligence in the form of visual display of important information that is used on the user interface to support a decision.

By displaying the data visualization aims to ease the user both students and teachers in looking at the data and speed up the process in decision making. The operational data of the iLearning Mediadevelopment data mart to display information dashboard. Operational data is the database used to store data of the post and the comments made by teachers and students for research time lasts up to be used with unlimited time. Highcharts else needed to display the dashboard a dynamic chart in accordance with the existing data in the database of iLearning Media. The next step is the design or redesign of a system to repair or renew the old system as well as providing a clear picture on the users of the system design process from beginning to end.

OLAP technique is done with Drill-down i.e. collect the post data and comment from the rest of the year, semester and the Moon in detail will be shown based on the classes that exist in this research, is then displayed in the form of dashboards in the form of tables and graphs. The dashboard will be designed consisting of 5 dimensions, i.e. users, user permissions, time, articles, and comments.After the data mart, do page development that is capable of showing the performance of the class of the article and the comments contained in the MOLAP and then displayed in the form of a dashboard.

The dashboard will be designed consisting of three facts, i.e. mostarticle writer, most commentators, and most helpful articles. Thusthree of these facts will be made of the fact table. In designing this, data mart schema used is the Snowflake scheme for each Dimension Table and the Fact Table associated with it. Where there is a table of the dimensions that are used for three different Fact tables are causing many to one between the relational foreign key in the fact tables. These dimensions are the dimensions of the Period, the dimensions of the user (dim_wp_users), the dimension of the access rights of the user (dim_wp_usermeta), the dimensions of the articles (dim_wp_posts), the dimension of Sub-site (dim_wp_blogs). Solving the scheme based on the table of his facts, described in the scheme-the scheme in Figure 2 below,

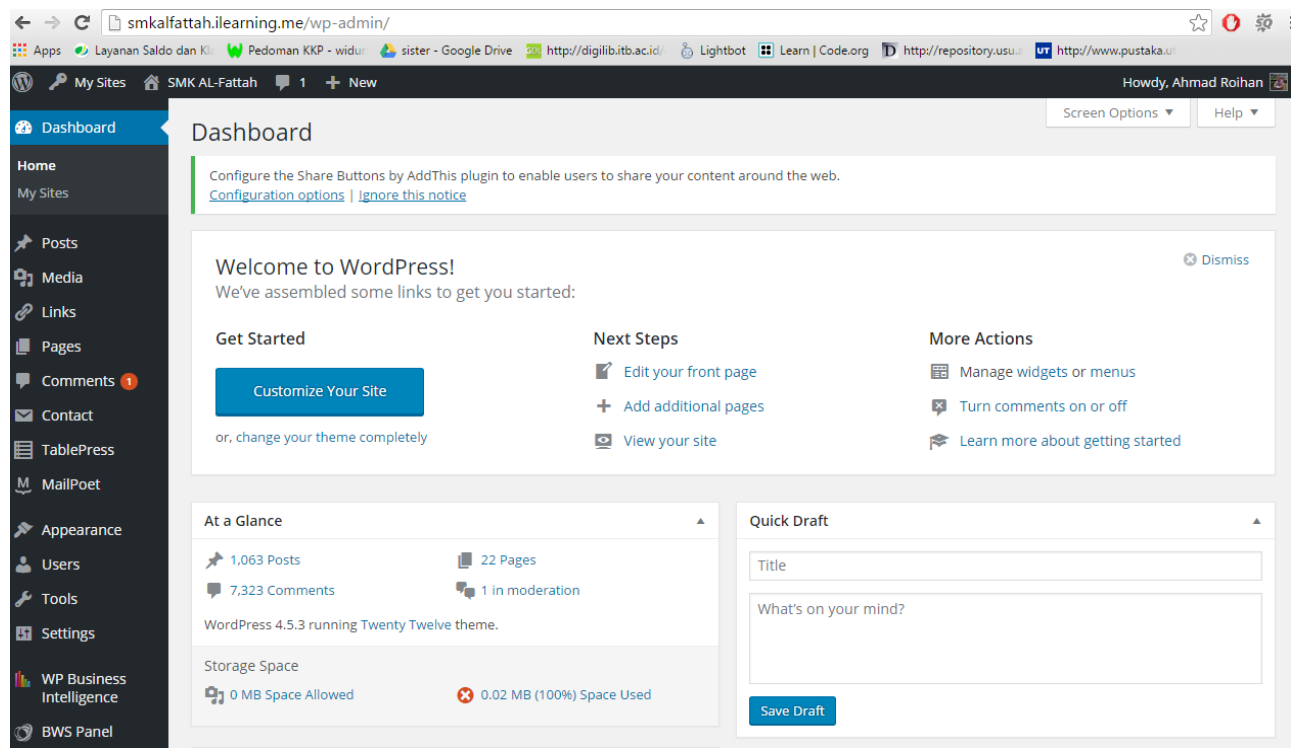

Source: http://smkalfattah.ilearning.me/wp-admin/

Figure 2. The Dashboard System iLearning Media 

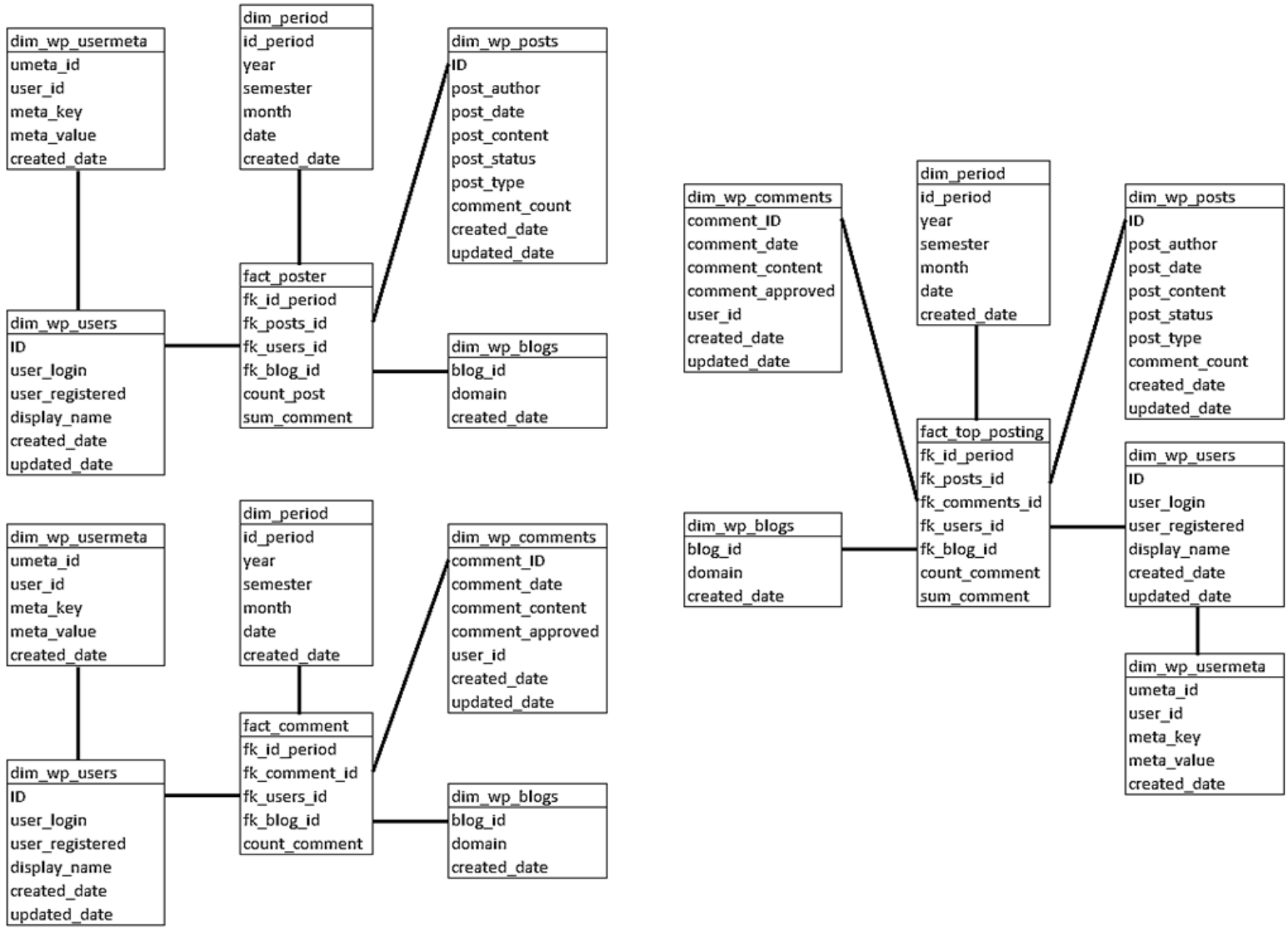

Figure 3. Three Fact Tables iLearning Media

User access rights are required for user classification process that would later be used as classes in the dashboard smkalfattah.ilearning.me. This classification will distinguish the classes that existing this research. Therefore an additional plugin is required to make the access rights this user. Then the plugin was selected User Role Editor to create it. As for the addition of user access rights in this research as much as 3 user i.e. SOJ15X Author AS15XI, Author, and AS15XII Author. As for the teacher, it still remains with user access rights that exist in the system of Media i.e. iLearning iMe User.

\section{Implementation}

The dashboard is the result of insert or embed from an already Highcharts processed data as well as it looks. Later in the design also requires a plugin PHP Code For Posts installed on iLearning Media. As for the function of PHP Code For Posts itself i.e. can add the PHP code into the admin options page and then display the outputaccording to your needs and it is only by using the shortcode only.Some code snippets can be used at posts, and some posts may use the same piece of code, which allows the user to reuse the code. Shortcodes can be used also for showing ordinary HTML content, it allows users to add in an iframe, object, and other tags issued by the editor posting the page. The plugin can also contain a variable array that is used to add variables. Example shortcode is added on every post is [php snippet $=1]$. The display on the dashboard page consists of a chart and a table of the largest article writer, most Commentators, and most helpful Articles. Following is the result from the design of Business Intelligence in the system of learning Media, iLearning

\subsection{The Author of The Article Most}

Display this dashboard is the result of processing a query MySQL and PHP programming language using PHP Code For Posts and Highcharts from table facts with dimension tables wp_posts, wp_users, and wp_usermeta.

\subsection{Most Comment}

This dashboard display is a fact table with the dimension tables wp_posts, wp_comments, wp_users, and wp_usermeta. 


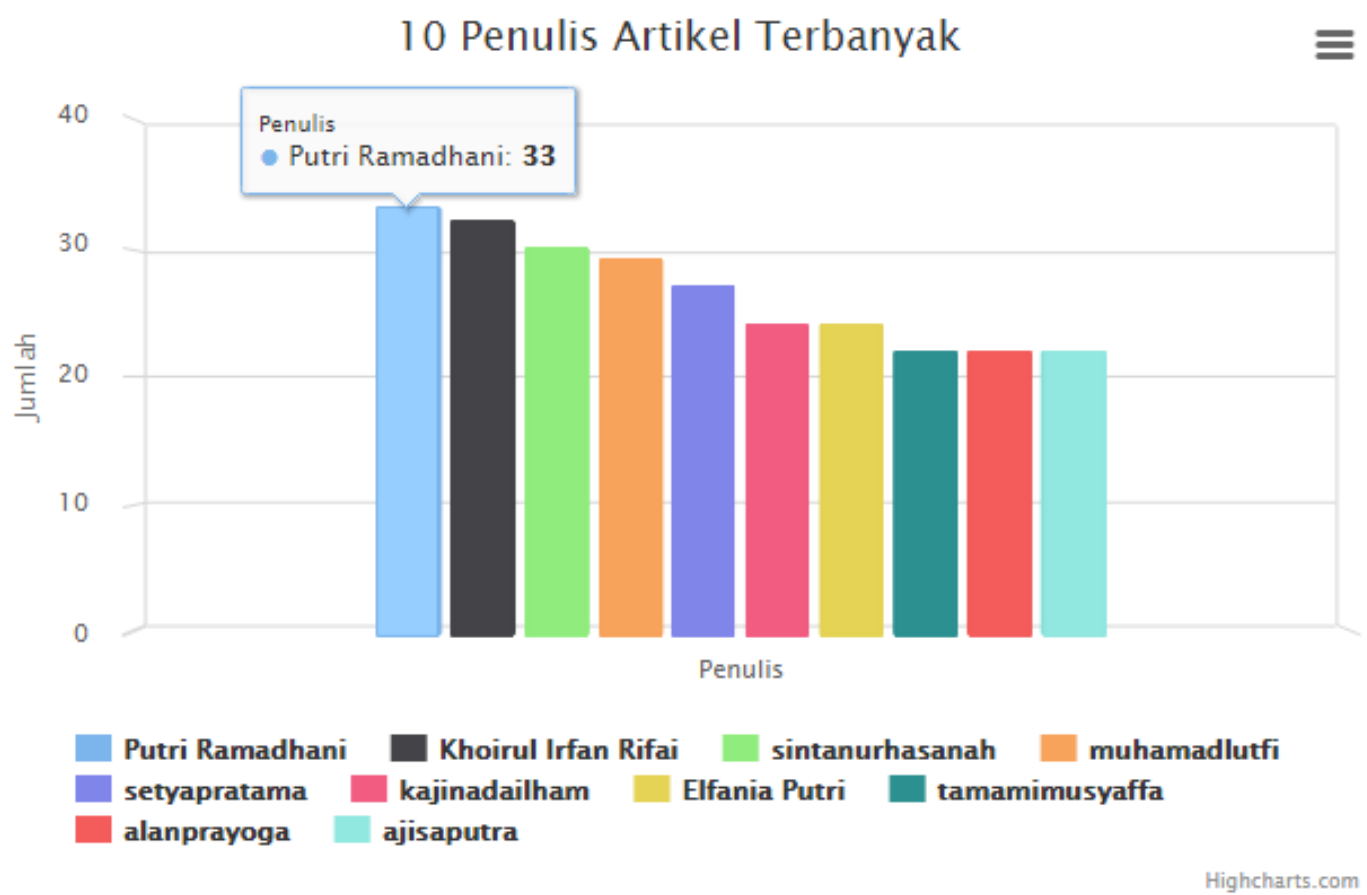

Figure 4. Dashboard 10 Most article writer

\section{3. the Most Useful Article}

This dashboard display is a fact table with the dimension tables wp_posts, wp_comments, wp_users, and wp_usermeta. As for the formula or the formula that is used to get the value of the article with the summation of results between the number of comments, the length of the string or character of the comment in the article, and the length of the string or character of the article, it is in accordance with Figure 5 below.

\section{Komentator Terbanyak}

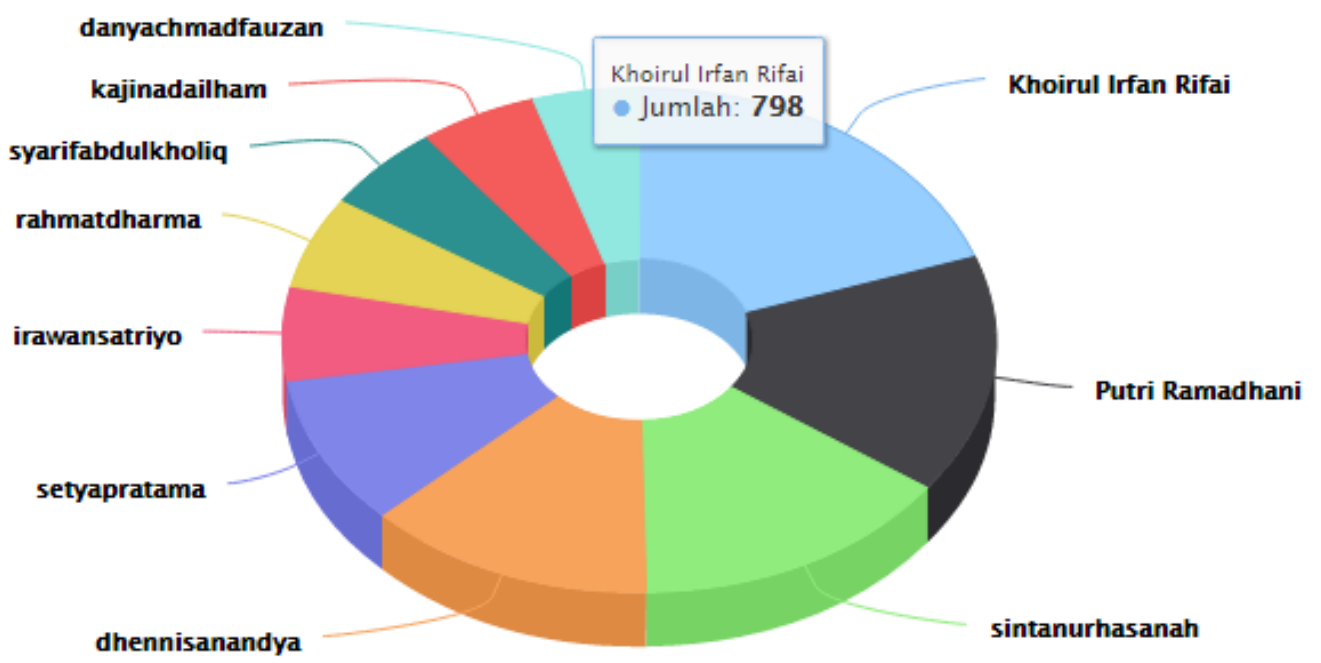

Figure 5. 10 Most Commentators Dashboard 


\section{Detail Poin Dashboard}

20 Artikel paling bermanfaat yang tercatat dalam ALFiL Class sampai tanggal 12 Aug 2016

\begin{tabular}{|c|c|c|c|c|c|c|c|}
\hline NO & JUDUL ARTIKEL & NAMA & \begin{tabular}{|c|} 
JUMLAH \\
KOMENTAR
\end{tabular} & $\begin{array}{l}\text { PANJANG } \\
\text { KOMENTAR }\end{array}$ & $\begin{array}{l}\text { PANJANG } \\
\text { ARTIKEL }\end{array}$ & $\begin{array}{l}\text { POMLAH } \\
\text { POIN }\end{array}$ & KELAS \\
\hline 1 & $\begin{array}{l}\text { Modul Melakukan Installasi } \\
\text { Perangkat Jaringan Lokal (LAN) } \\
\text { \#Rangkuman }\end{array}$ & tamamimusyaffa & 3 & 238 & 31992 & 32233 & $\begin{array}{l}\mathrm{XI} \\
\mathrm{TKJ}\end{array}$ \\
\hline 2 & $\begin{array}{l}\text { Apa sih indihome itu? saya make } \\
\text { apa engga? }\end{array}$ & setyapratama & 9 & 287 & 29982 & 30278 & $\begin{array}{l}\mathrm{XI} \\
\mathrm{TKJ}\end{array}$ \\
\hline 3 & Televisi Internet $(\wedge \wedge)$ & setyapratama & 8 & 1108 & 21987 & 23103 & $\begin{array}{l}\mathrm{XI} \\
\mathrm{TKJ}\end{array}$ \\
\hline 4 & $\begin{array}{l}\text { Cara Menyelesaikan Rubik } 3 \times 3 \\
\text { Dengan mata tertutup }\end{array}$ & $\begin{array}{l}\text { Khoirul Irfan } \\
\text { Rifa'ì }\end{array}$ & 6 & 124 & 22230 & 22360 & $\begin{array}{c}X \\
\text { TKJ }\end{array}$ \\
\hline 5 & Dasar-Dasar Pada HTML & rahmatdharma & 7 & 224 & 21633 & 21864 & $\begin{array}{c}X \\
\text { TKJ }\end{array}$ \\
\hline 6 & SKUP-SOJ Khoirul Irfan Rifa'i & $\begin{array}{l}\text { Khoirul Irfan } \\
\text { Rifa'i }\end{array}$ & 456 & 10340 & 8112 & 18908 & $\begin{array}{c}X \\
\text { TKJ }\end{array}$ \\
\hline 7 & Cara Menyelesaikan Rubik $3 \times 3$ & Khoirul Irfan & 1 & 29 & 18691 & 18721 & $\mid \begin{array}{c}X \\
\text { TVI }\end{array}$ \\
\hline
\end{tabular}

Figure 6. Details and formulas Dashboard 10 most helpful Articles

\section{Artikel Paling Bermanfaat}

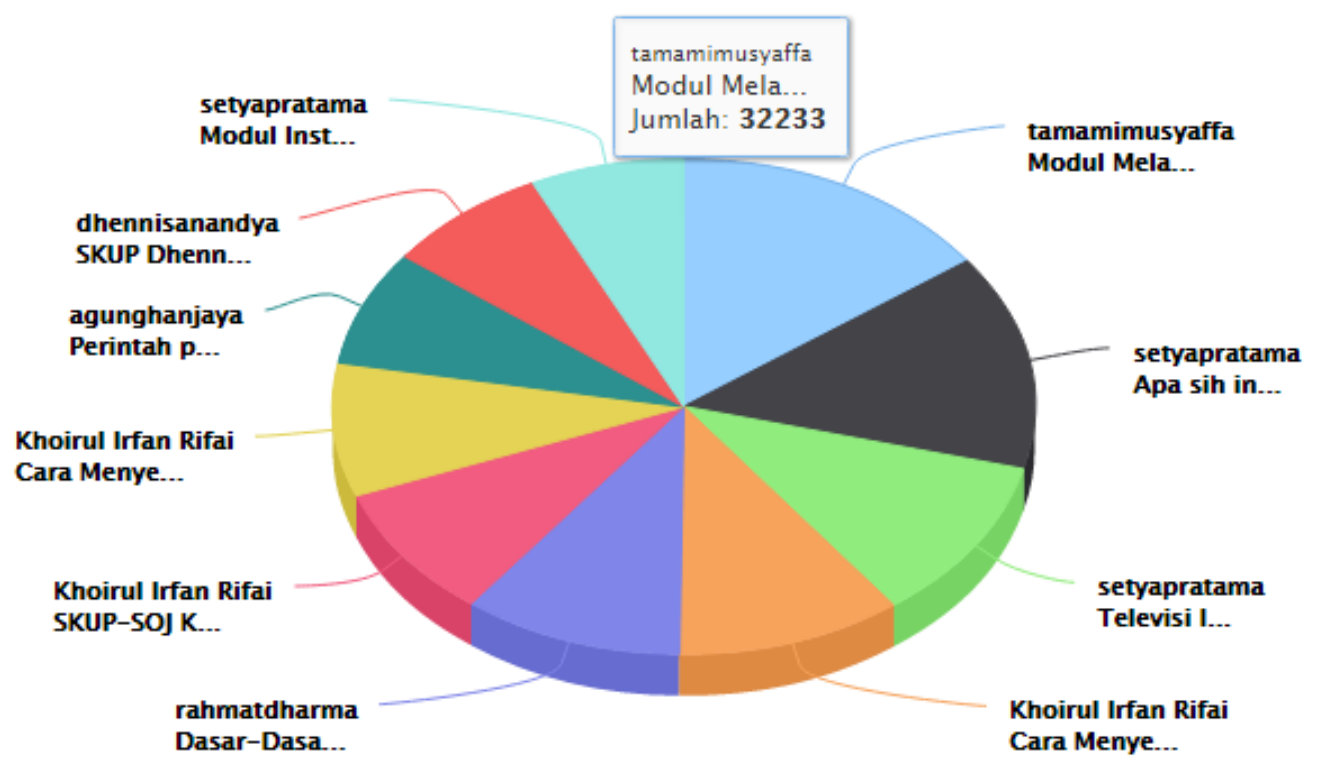

Figure 7. 10 Most Useful Article Dashboard 
Based on the results of this dashboard display, teachers automatically get the information detail liveliness and students support in decision-making. Further based on the level of participation can be measured based on the existing dashboard display. Then the dashboard can also measure user interests and liveliness in the wear online learning system applications using the iLearning Media.

\section{Conclusions}

The design of the learning system iLearning concept and accompanied Media device from the business intelligence that is by adding the dashboard on that system, it can be stated that it could support a teacher in terms of decision-making based onthe enthusiasm of the students in your task as well as interact and communicate better with teachers as well as between the student can be measured and proven learning process more effective. Furthermore the system implemented in the level of participation can be measured based on the existing dashboard display. Then the dashboard can also measure user interests and liveliness in the wear online learning system applications using the iLearning Media. It can be proved that the design and implementation of business intelligence system iLearning Media in SMK AL Fattahis highly effective both in terms of communication, interaction, and time.

\section{REFERENCES}

[1] Hamdani. "Strategi Belajar Mengajar". CV Pustaka Setia: Indonesia, 2011.

[2] Alkhalaf, Salem, Drew, Steve, Alghamdi, Rayed, Alfarraj, Osama ."E-learning system on higher education institutions in KSA: attitudes and perceptions of faculty members". North Cyprus, Procedia - Social and Behavioral Sciences Volume 47 2012. Diakses dari

http://www.sciencedirect.com/science/article/pii/S187704281 2025360 Tanggal 15 Januari 2016 Pukul 03.40 WIB.

[3] Luo, Guo-Heng, Liu, Eric, Zhi-Feng, Kuo, Hung-Wei, Yuan,
Shyan-Ming. "Design and Implementation of a Simulation-Based Learning System for International Trade". Athabasca, AB T9S 3A3 Canada, International Review of Research in Open and Distance Learning (IRRODL) Vol. 15 Athabasca University 2014. Access on http://www.irrodl.org/ index.php/irrodl/article/view/1666/2816 23 Januari 2016.

[4] Rahardja, Untung, Sudaryono, Irwan Nurdin. "Implementasi iMe (iLearning Media) Dalam Mendukung Sistem Pembelajaran iLearning Pada Perguruan Tinggi”. Tangerang, CCIT Journal Vol. 8 STMIK Raharja, 2014

[5] Deborah, L. Jegatha, R. Baskaran, A. Kannan. "Learning styles assessment and theoretical origin in an E-learning scenario: a survey". Springer Science+Business Media B.V.: Germany, 2012.

[6] Debevca, Matjaz, Zoran Stjepanovic, Andreas Holzingerc. "Development and evaluation of an e-learning course for deaf and hard of hearing based on the advanced Adapted Pedagogical Index method". Interactive Learning Environment: United Kingdom, 2014

[7] Chou, Hsin-Kai, I-Chun Lin, Lin-Chung Woung, Ming-Tsu Tsai. "Engagement in E-Learning Opportunities: An Empiricial Study on Patient Education using Expectation Confirmation Theory". Springer Science+Business Media B.V.: Germany, 2010.

[8] Marti'nez-Caro, Eva. "Factors Affecting Effectiveness in E-Learning: An Analysis in Production Management Courses". Business Management Department, Universidad Polite'cnica de Cartagena: Spain, 2009.

[9] Benchicou, Soraya, Mohamed Aichouni and Driss Nehari. "E-learning in engineering education: a theoretical and empirical study of the Algerian higher education institution" Europian Journal of Engineering Education: United Kingdom, 2010.

[10] Guritno, Suryo, Sudaryono, Untung, Rahardja. "Sistem Informasi Manajemen". PT Remaja Rosdakarya: Bandung, 2013.

[11] Rahardja, Untung, Desrianti, Dewi, Immaniar, Mawadah, Siti. "iBooks Standardisation and Good Practice for Effective Education Methods Insupport of iLearning". Tangerang, CCIT Journal Vol. 5 STMIK Raharja, 2011.

[12] Turban, Efraim. "Decision Support and Business Intelligence Systems/ Efraim Turban, Ramesh Sharda, Dursun Delen - 9th ed". New Jersey, Pearson Education, Inc, 2011. 